Original Research Paper

\title{
Role of Energy and Exports in Economic Growth in Ghana
}

\author{
Joseph Adu \\ Department of Banking and Finance, University of Professional Studies, Accra, Ghana
}

\author{
Article history \\ Received: 24-10-2018 \\ Revised: 01-12-2018 \\ Accepted: 01-02-2019 \\ Email: kwakuadu84@yahoo.com \\ joseph.adu@upsa.edu.gh
}

\begin{abstract}
For many years, the quest for sustained economic growth has remained a paramount agenda for developing and emerging economies. However for many of these economies, this goal remains elusive as the myriad of reforms implemented have often failed to yield desired results. The literature is replete with many studies aimed at identifying the sources of growth. Yet the role of energy access and utilization has received little attention, likewise the role of exports. To fill this void and offer direction to policy in emerging economies, this study attempts to investigate the impact of energy use and exports in fostering economic growth and development using Ghanaian data. Findings from this paper reveal that energy consumption and exports are key drivers of economic growth in Ghana. Hence, development policy in the country and beyond must be designed to give careful consideration towards integrating energy policy and export-promotion in order to harness the growth potentials of other sectors of the economy.
\end{abstract}

\section{Keywords: Energy, Export, Economic Growth, Ghana}

\section{Introduction}

The quest for economic growth has been pursued rigorously by economies around the world since the great depression. In the developing world, myriads of pro-growth policies have been prescribed and implemented but with varying impacts on economic development of host countries. For instance, development experts opine the structural adjustment and economic liberalization policies prescribed by the International Monetary Fund (IMF) and the World Bank and implemented in Sub-Saharan African economies in the 1980s-90s did not yield the needed impact of spurring growth in the region (Cornia and Helleiner, 1994; Stewart, 1991; UNRISD, 1995; Killick, 1996).

In recent times however, development policy in developing and emerging economies have been focused on attracting foreign direct investment and boosting exports. The success of these policies in generating the needed growth depends to a large extent on the provision of infrastructure particularly energy. Energy has evolved over the years to become the bloodline of every economy as it drives every sector and plays a key role in the efficient function of the economy (Mensah, 2014). Thus production, distribution and consumption of goods and services in all sectors of the economy hinge on the supply of reliable energy services (Mensah, 2014).

In recognition of the importance of energy services in economic development, energy policy in Ghana has been focused mainly on improving access to energy in both urban and rural communities. Examples of such programs include: The Rural Electrification Programme (REP), National Electrification Scheme (NES), National LPG Promotion Campaign initiated in 1972, 1989 and 1990 respectively. These policies have contributed immensely towards expanding access and utilization of modern energy sources like electricity and LPG among households and industries. Nevertheless, the energy sector is still plagued with challenges as evidenced by the perennial crises in the sector especially with regards to electricity supply. At the same time the export sector has been booming and increasingly being diversified from traditional export commodities like gold, cocoa, timber and diamonds to include non-traditional exports like crafts, agricultural produce (mango, pineapple, etc) and recently oil.

In recent past, the Ghanaian economy has been ranked as among the fastest growing economies in the world, with economic growth hitting a record high of $15 \%$ in 2011. Now, whereas several attempts have been made in the literature to identify the sources of growth in the Ghanaian economy, little is said of the role that energy access and utilization as well as the export sector play in the economic development of the country. Yet, the literature on the energy-growth nexus emphasize the importance of energy consumption in inducing economic growth especially in developing and emerging economies, with a quest for industrialization. Again, a careful look at the sectoral shares of total exports in Ghana reveal 
dominance of the energy-dependent extractive sectormining. This suggests the existence of strong interlinkages between energy consumption, exports and real output in the Ghanaian economy: Which unfortunately has so far not received any attention in the research front. To this end, the questions that beckon are: What is the relationship between energy consumption, export and economic growth in Ghana? To what extent do shocks in the energy and export sectors affect the economy's growth trajectory? Answers to these gaping questions are crucial and will be of immense benefit to economic policy design especially in identifying how energy policy and export promotion campaigns can be coordinated to promote the overarching goal of engendering growth and development. Hence, the need for this study; as these questions form the nucleus of this paper.

This paper differs from other studies extant in the literature especially on the energy-growth nexus, in the sense we deviate from the usual bivariate approach of examining causality between energy consumption and real GDP (Esso, 2010; Zachariadis, 2007) by examining the issues within a multivariate framework. This approach is important towards reducing the potential problem of omitted variable bias in the bivariate case. Again, this study offers an avenue for policy makers to access the impact of the pro-export programs instituted in the country since the implementation structural adjustment programs in the 1980s, by delineating the impact of the exports on economic growth in Ghana.

Results from this study, give credence to the energyled-growth hypothesis but raises questions on the possibility of the export-led-growth hypothesis in the Ghanaian case. Other factors such as financial development were also found to be a significant determinant of economic growth in Ghana. The policy implications stemming from the paper is that efforts aimed at enhancing access and utilization of efficient and reliable supply of energy services will be growth enhancing and vice versa. Again, diversification and value addition should be a central theme of export promotion policies in the country in order to engender greater benefits to the economy.

The rest of the paper is structured as follows. Section 2 presents a review of relevant literature. In section 3 , we describe the methodology and empirical strategy, while section 4 focuses on the discussion and analysis of the results. Section 5 concludes and presents the policy implications from the study.

\section{Review of Literature}

Economic growth and its relationship with energy as well as exports have largely been discussed in the energygrowth and growth-export literature. The relationship between energy use and economic growth has been implicitly confirmed by economic theories. This has called for several studies to conducting causality tests with diverse statistical techniques to identify causal nexus between energy use and the level of output (Halicioglu, 2011).

Recent empirical literature on economic growth and energy use identify four main hypotheses namely growth, conservation, neutrality and feedback (Payne, 2010). Thus, if unidirectional causality runs from energy use to economic growth, then a rise in energy use could lead to an increase in economic growth. Here, energy is seen in the literature as an indispensable input for production without which other factors of production like capital and labour cannot be used effectively. Energy consumption is therefore regarded to be a limiting factor to economic growth. On the other hand, if unidirectional causality runs from economic growth to energy use then decreasing energy use may have little or no negative effect on economic growth. Furthermore, energy is seen to be neutral to economic growth, in what is famously termed as neutrality hypothesis. The explanation of the neutrality of energy to economic growth stems from the fact that the cost of energy is very small as ratio of output (Halicioglu, 2011).

It is worth noting that empirical outcomes of studies on economic growth-energy differ in terms of time period, country, econometric techniques and proxy variables. Guttormsen (2004) using the generation criteria, have classified studies on energy-growth into first generation, second generation and third generation studies. Studies that basically use the Vector Autoregressive Models (Sims, 1972) and the standard Granger causality tests are the first generation models. On the other hand, the second generational models are base on exploring bivariate relationships among variables by applying cointegration approaches of Johansen and Juselius (1990) and Engle and Granger (1987). The third generation models propose a multivariate approach that allows for more than two variables in the cointegration relationship. Although these studies are not bereft of limitations (Adom, 2011), advancement in statistical methods and techniques ensure that results ensuing from these studies are not spurious.

Empirical survey outcomes on growth-energy nexus differ in terms of time period and statistical techniques. These results in varying conclusions in offering policy recommendations that cannot be apply across countries with similar economic conditions. In a related study, Ozturk (2010) classified studies on energy-growth into country-specific and multi-country studies. Countryspecific studies on energy-growth include (Adom, 2011; Halicioglu, 2011; Yoo and Kwak, 2010; Lean and Smyth, 2010; Twerefo et al., 2008; Akinlo, 2008; Mensah, 2013 among others) and multi-country studies include (Ouedraogo, 2013; Wolde-Rufael, 2009 among others. Country-specific results mostly favour causality running from electricity to economic growth. On the other hand, causalities from multi-country studies are contradictory (Ozturk, 2010). 
The relationship between economic growth and exports is not new in growth-export literature. The prominent view is that exports are seen as engine of economic growth. In the export-growth literature, export growth leads to the following; (1) an increase in demand for the country's output; (2) promote specialization which enhances the productivity level; (3) export promotion reduces depreciation of the domestic currency; (4) countries with high export/output ratios are more open to outside influences and generate externalities such as the incentive to innovate. These form the basic tenet of the export-led growth hypothesis. On the other hand, Lancaster (1980) suggested that economic growth leads to enhancement of skills and technology. This increased efficiency creates a comparative advantage for the country that facilitates exports. This has been termed as growth-led export hypothesis. Furthermore, exports may rise from the realization of economies of scale due to productivity gains; the rise in exports may further enable cost reductions, which may result in extra productivity gains (Helpman and Krugman, 1985). This is the feedback relationship between exports and out.

The relationship between exports and energy is derived in the empirical literature although they do not have any economic theory backing (Halicioglu, 2011). A unidirectional causality may run from exports to energy which implies that energy saving policies have no adverse impact on export growth. However, a reverse causality from energy consumption to exports implies that reduction in energy use will limit expansion in exports which are considered to be engine of economic growth.

The preceding review highlights the growing literature on energy use, economic growth and exports. However, it must be emphasized that most of the extant literature examine the issue from the perspective of energy and growth, exports and growth and exports and energy. Based on this one would conjecture that given the key role of energy use and exports in spurring growth especially in developing and emerging economies, a study that seeks to provide empirical evidence on the actual growth impact of energy and exports will be worthwhile. Hence, this study.

\section{Model Specification, Data and Methodology}

To demonstrate theoretically, the role of energy and export in driving output, we assume a simple A-K type production function:

$Y_{t}=A_{t}^{\alpha} K_{t}^{\phi}$

where, $K_{t}$ is the capital endowment of the country, while $A_{t}$ is the productivity parameter. For simplicity were assumed that energy and exports influence output via productivity changes. We assume that the productivity parameter can be expressed as a function of energy $\left(E_{t}\right)$, exports $\left(X_{t}\right)$ and an exogenous productivity factor $\left(A_{0}\right)$, viz:

$A_{t}=f\left(E_{t}, X_{t}, A_{0}\right)$

Substituting (2) into (1) we obtain:

$Y_{t}=A_{0}^{\alpha} X_{t}^{\alpha} E_{t}^{\alpha} K_{t}^{\phi}$

Taking a log-linearization result in:

$\ln Y_{t}=\gamma+\alpha_{1} \ln X_{t}+\alpha_{2} \ln E_{t}+\phi \ln K_{t}$

where, $\gamma=\ln A_{0}$.

However, the identification of parameters especially $\left(\alpha_{1}\right)$ is an empirical challenge since exports by virtue of the conventional national income accounting is part of output. That is, $\alpha_{1}$, cannot be assumed to measure the effect of an exogenous shock in exports on output. To overcome this identification challenge, we replace output with non-export GDP which is obtained by netting out the contribution of exports incorporated via the national income identity (Dreger and Herzer, 2013; Siliverstovs and Herzer, 1994; Greenaway and Sapsford, 1994).

Non-export GDP can be defined as:

$N Y_{t}=Y_{t}-X_{t}$

Therefore specifying (4) in terms of non-export GDP results in:

$\ln N Y_{t}=\beta_{0}+\beta_{1} \ln X_{t}+\beta_{2} \ln E_{t}+\beta_{3} \ln K_{t}$

where, $\beta_{3}$ can now be properly identified. $\beta_{3}>0$ imply a real growth a real growth effect of export via increasing productivity in output rather than mere increase in export volumes. On the other hand, $\beta_{3}>0$ suggest a productivity reducing output of export (Siliverstovs and Herzer, 1994).

\section{Model Specification and Data}

Following from the previous section, we augment the reduced form model in Equation (6) with a set of covariates including, financial development $\left(F D_{t}\right)$ and foreign aid $\left(A i d_{t}\right)$. The choice of these covariates was informed by the evidence from the empirical literature. Therefore, the empirical model estimated in this paper is represented by:

$$
\begin{aligned}
& \ln Y_{t}=\beta_{0}+\beta_{1} \ln K_{t}+\beta_{2} \ln E_{t}+\beta_{3} \ln X_{t} \\
& +\beta_{4} \ln \text { Aid }_{t}+\beta_{5} \ln F D+\mu_{t}
\end{aligned}
$$

where, $\beta_{i}$ and $\mu_{t}$ represents the coefficient of the regressors and error term respectively. 
A priori based on theory, we expect a the level of capital stock in the economy to exert a positive impact on economic growth as the provision of physical capital in the form of infrastructure etc provides an enabling environment for the efficient function of the economy. Moreso, for an emerging economy like Ghana, with a boyant export sector dominated by agriculture and the energy intensive extractive sectors, we expect both energy consumption and exports to be positive drivers of growth in the economy. Also, financial development expected to impact economic growth positively, as a well-functioning financial sector is regarded as sine-quanon to the growth of the real sector by facilitating the process of financial intermediation between deficit and surplus spending units. The anticipated impact of aid on growth is however, mixed: Which is evident in results from the empirical literature (Minoiu and Reddy, 2009).

To achieve the goal of the study, we employ the use of annual time series data on energy consumption, gross fixed capital formation (as a proxy for capital stock), real GDP, aggregate export, official development assistance (Aid) and domestic credit of private banks and other financial institutions as a \% GDP (as a proxy for financial development) spanning from 1971-2011. All data except aggregate exports were sourced from the World Bank's World Development Indicators (WDI), 2013. Export data were however sourced from UNSTAT database.

\section{Econometric Approach}

The empirical approach used in the analysis of this paper is summarized as follows: First, in line with the requirements of time series analysis we examine the unit root properties of the data using the robust Phillip Peron (PP) unit root test. This is necessary to ensure the absence of a mean reverting process in the series being modeled as the use of non-stationary data might yield spurious results. Second, we test for the presence of long run equilibrium relationship between the variables being modelled using the Johansen and Juselius (1990) multivariate cointegration procedure. Given the establishment of a long run cointegration relationship between economic growth and its regressors, we proceed to estimate the long run relationship between the variables using the Fully Modified Least Squares (FMOLS) cointegration model propounded by Phillips and Hansen (1990). Finally, to ascertain the actual contributions of the energy consumption, exports and the other covariates to variations in real non-export GDP, the Variance Decomposition technique is applied. For robustness check, we estimate a variant of the long run model with real GDP as the dependent variable. Also for the nonexport GDP model, several specifications are estimated.

For brevity and without loss of generality, the theoretical description of the various techniques used in the analysis is exempted from the present study. For an exposition on these techniques, readers may refer to Phillips and Hansen (1990), Johansen and Juselius (1990), Greene (2012) etc.

\section{Results}

\section{Unit Root Properties}

The establishment of a long run cointegration relationship between economic growth and its long run drivers require knowledge of the stationarity properties of the variables and consequently its order of integration. The latter is crucial in determining the choice of the cointegration technique to adopt. For robustness, this study uses the Phillip- Peron (PP) tests with trend and intercept to test for the unit root properties of the series. The results (Table 1) show that all the series achieved stationarity after the first difference (i.e., the series are integrated of order one $\mathrm{I}(1)$ ).

\section{Test for Long-Run Equilibrium}

The results from the unit root test reveal that all the series attain stationarity after first difference. This result therefore informs the choice of the Johansen cointegration approach to test for the existence of long run equilibrium in estimated model as shown in Equation 2. From the results in Table 2, both the maximum Eigen value and Trace statistics confirm the rejection of the null hypothesis of no cointegration equation in favor of the alternative hypothesis of one cointegration equation in the model which corresponds to the model with real GDP and real non-export GDP as the dependent variables. In other words, the ensuing results from the cointegration tests confirm the presence of a long run equilibrium relationship between real GDP and real nonexport GDP and their respective long run forcing variables i.e., energy consumption, exports, capital, financial development and foreign aid.

\section{Long Run Determinants and Discussion}

According Phillips and Hansen (1990), in the presence of I(1) series the FMOLS technique suffices as a robust technique in estimating the long run relations between variables, without having to use any of the conventional cointegration techniques. Nonetheless, results in the preceding section based on the conventional cointegration approach, Johansen test, indeed attest to the presence of a cointegration relationship in the model estimated. In consequence, we proceed to examine the long run impact of energy consumption, exports and the other long run forcing variables on the economic growth trajectory in Ghana using the FMOLS technique. The Parzen kernel estimator is applied to derive robust standard errors. Results are shown in Table 3. 
Table 1: PP unit root tests

\begin{tabular}{llll}
\hline & Phillip-Perron test & & Order of \\
Variables & - & First difference & integration \\
\hline Financial development & Level & $-5.522 * * *$ & I $(1)$ \\
Energy consumption & -3.120 & $-7.692 * * *$ & I $(1)$ \\
Export & -2.739 & $-7.394 * *$ & $\mathrm{I}(1)$ \\
Gross capital formation & -1.356 & $-7.220^{* * *}$ & $\mathrm{I}(1)$ \\
Aid & -2.884 & $-9.143 * * *$ & $\mathrm{I}(1)$ \\
Real GDP & -1.823 & $-5.290^{* * *}$ & $\mathrm{I}(1)$ \\
Real non-export GDP & $-15.324 * * *$ & $\mathrm{I}(1)$ \\
\hline
\end{tabular}

${ }^{+}$model with intercept; $* * *$ indicates $1 \%$ significance level

Table 2: Johansen Cointegration results

\begin{tabular}{|c|c|c|c|c|c|c|}
\hline \multirow[b]{2}{*}{$\begin{array}{l}\text { Hypothesized } \\
\text { no. of Coint. } \\
\text { equations }\end{array}$} & \multicolumn{3}{|c|}{ Model with real GDP } & \multicolumn{3}{|c|}{ Model with real non-export GDP } \\
\hline & $\begin{array}{l}\text { Eigen } \\
\text { Value }\end{array}$ & $\begin{array}{l}\text { Maximum Eigen } \\
\text { Statistics }\end{array}$ & $\begin{array}{l}\text { Trace Statistics } \\
\text { Statistics }\end{array}$ & $\begin{array}{l}\text { Eigen } \\
\text { Value }\end{array}$ & $\begin{array}{l}\text { Maximum } \\
\text { Eigen }\end{array}$ & $\begin{array}{l}\text { Trace } \\
\text { Statistics }\end{array}$ \\
\hline $\mathrm{r}=0$ & 0.798307 & $60.83836 * * *$ & $148.0096 * * *$ & 0.815875 & $64.30132 * * *$ & $157.2849 * * *$ \\
\hline$r=1$ & 0.573474 & 32.37909 & $87.17121 *$ & 0.582572 & 33.19841 & $92.98353 * *$ \\
\hline$r=2$ & 0.500271 & 26.36020 & 54.79212 & 0.531012 & 28.77281 & 59.78511 \\
\hline$r=3$ & 0.321257 & 14.72549 & 28.43192 & 0.345619 & 16.11448 & 31.01231 \\
\hline
\end{tabular}

***indicates $1 \%$ significance level; *indicates $10 \%$ significance level

Table 3: Long-run determinants from FMOLS approach

\begin{tabular}{|c|c|c|c|c|c|}
\hline \multirow[b]{3}{*}{ Regressors } & \multicolumn{5}{|c|}{ Dependent variable } \\
\hline & \multirow{2}{*}{$\begin{array}{l}\text { Real GDP } \\
\text { (1) }\end{array}$} & \multicolumn{4}{|c|}{ Real non-export GDP } \\
\hline & & $(2)$ & $(3)$ & $(4)$ & $(5)$ \\
\hline Intercept & $\begin{array}{l}12.777 * * * \\
(0.6683)\end{array}$ & $\begin{array}{l}23.305 * * * \\
(0.7358)\end{array}$ & $\begin{array}{l}18.598 * * * \\
(0.9861)\end{array}$ & $\begin{array}{l}22.732 * * * \\
(1.0887)\end{array}$ & $\begin{array}{l}20.437 * * * \\
(0.9222)\end{array}$ \\
\hline Aid & $\begin{array}{l}-0.0717 * * \\
(0.0266)\end{array}$ & $\begin{array}{l}-0.1720 * * * \\
(0.0293)\end{array}$ & $\begin{array}{l}-0.2031 * * * \\
(0.0584)\end{array}$ & $\begin{array}{l}-0.2629 * * * \\
(0.0394)\end{array}$ & \\
\hline Gross Capital Formation & $\begin{array}{l}-0.0814 * * \\
(0.0388)\end{array}$ & $\begin{array}{l}0.0329 \\
(0.0427)\end{array}$ & $\begin{array}{l}0.1133 \\
(0.0734)\end{array}$ & & $\begin{array}{l}0.0953 * \\
(0.0492)\end{array}$ \\
\hline Exports & $\begin{array}{l}0.0842 * \\
(0.0459)\end{array}$ & $\begin{array}{l}-0.7537 * * * \\
(0.0506)\end{array}$ & $\begin{array}{l}-0.4250 * * * \\
(0.0742)\end{array}$ & $\begin{array}{l}-0.7844 * * * \\
(0.0750)\end{array}$ & $\begin{array}{l}-0.4478 * * * \\
(0.0559)\end{array}$ \\
\hline Energy Consumption & $\begin{array}{l}0.9354 * * * \\
(0.0736)\end{array}$ & $\begin{array}{l}1.7024 * * * \\
(0.0811)\end{array}$ & $\begin{array}{l}1.4719 * * * \\
(0.1565)\end{array}$ & $\begin{array}{l}1.878996 * * * \\
(0.1184)\end{array}$ & $\begin{array}{l}1.2603 * * * \\
(0.0833)\end{array}$ \\
\hline Financial Development & $\begin{array}{l}0.1421 * * * \\
(0.0407)\end{array}$ & $\begin{array}{l}0.2922 * * * \\
(0.0449)\end{array}$ & & $\begin{array}{l}0.2719 * * * \\
(0.0575)\end{array}$ & $\begin{array}{l}0.0782 \\
(0.0572)\end{array}$ \\
\hline Diagnostics & & & & & \\
\hline Kernel estimator & Parzen & Parzen & Parzen & Parzen & Parzen \\
\hline N.W. Bandwidth & 4 & 4 & 4 & 4 & 4 \\
\hline N.W. Automatic lag length & 3 & 3 & 3 & 3 & 3 \\
\hline Pre-whitening lags & 2 & 4 & 4 & 4 & 4 \\
\hline D.W- Statistics & 0.83 & 1.01 & 1.29 & 1.06 & 1.10 \\
\hline
\end{tabular}

From the results of the two sets of models (real GDP and non-export GDP), we find similar impact estimates for all the regressors except exports and gross capital formation. However, given the identification issues associated with the former model, greater emphasis is place on the results emanating from the latter.

\section{Variance Decomposition}

Finally, in this section we assess the relative contribution of each variable (energy consumption, exports, gross capital formation, financial development and Aid) towards variations in real output using the variance decomposition technique. The result is depicted in Table 4. 


\begin{tabular}{|c|c|c|c|c|c|c|c|}
\hline Period & S.E. & LnNXY & LnK & $\operatorname{LnX}$ & $\mathrm{LnE}$ & LnFD & LnAid \\
\hline 1 & 0.228521 & 100.0000 & 0.000000 & 0.000000 & 0.000000 & 0.000000 & 0.000000 \\
\hline 2 & 0.240713 & 94.68798 & 1.094938 & 0.150498 & 0.589901 & 2.390302 & 1.086383 \\
\hline 3 & 0.245081 & 91.45851 & 1.865923 & 0.363176 & 0.574440 & 2.501509 & 3.236443 \\
\hline 4 & 0.249609 & 88.88157 & 2.037175 & 0.401630 & 1.177912 & 2.432768 & 5.068948 \\
\hline 5 & 0.250739 & 88.08276 & 2.358503 & 0.400826 & 1.507382 & 2.621120 & 5.029413 \\
\hline 6 & 0.253032 & 87.07559 & 2.657400 & 0.465937 & 2.035162 & 2.826388 & 4.939523 \\
\hline 7 & 0.254466 & 86.25323 & 2.963146 & 0.566187 & 2.456513 & 2.876455 & 4.884469 \\
\hline 8 & 0.255709 & 85.46846 & 3.409346 & 0.706011 & 2.717196 & 2.853087 & 4.845899 \\
\hline 9 & 0.256774 & 84.78815 & 3.822008 & 0.882496 & 2.871222 & 2.829878 & 4.806246 \\
\hline 10 & 0.257610 & 84.23928 & 4.172398 & 1.021338 & 2.968294 & 0.811782 & 4.786907 \\
\hline
\end{tabular}

Cholesky Ordering: LnY, LnK, LnX, LnE, LnFD, LnAid

\section{Discussion}

There is a strong positive long run growth impacts from energy consumption, financial development and exports. The study found a strong long run causality from energy consumption to economic growth and which is significant. This implies that energy consumption is a key driver of growth in Ghana since energy is a key input in the production process as well as the delivery of services. In other words, the rapid growth of the Ghanaian economy is associated with increased demand for energy to propel the engines of growth. Specifically, the study found out that a percentage increase in energy consumption is associated with a $0.93 \%$ growth in the economy. The obvious implication stemming from this result is that sustainable and efficient supply of energy services is instrumental to the realization of countries goal of becoming an uppermiddle income economy in the short-to-medium term. Thus it is imperative that efforts be implemented to address the perennial crises in the countries energy sector, especially the electricity and petroleum subsectors. This result is not uncommon in the empirical literature on energy-growth literature (see Ouedraogo, 2013; Odhiambo, 2009; Narayan and Prasad, 2008; WoldeRufael, 2006; Soytas and Sari, 2003). For instance, Wolde-Rufael (2006) in a study of 17 African economies find support for the energy-growth hypothesis. Similar findings were also derived by Narayan and Prasad (2008).

On the impact of exports, we find interesting results. Whereas a negative nexus is realized in the model with real non-export GDP, the results for the model with real GDP shows a positive nexus. This suggests that the positive effect obtained in the latter can be largely attributed to a "volume effect" of exports rather than a real productivity inducing impact. The impact of exports on growth of the non-export sector of the Ghanaian economy is negative. In other words, exports over Ghana over the study period has been "productivity reducing". This result albeit surprising, is not "alien" to the empirical literature on exports and growth (Dreger and Herzer, 2013; Siliverstovs and Herzer, 2007; Greenaway and Sapsford, 1994). As argued by Dreger and Herzer
(2013), the export-led-growth hypothesis may not necessarily apply in a developing country context, especially, in countries with heavily dependent on exports of primary commodities, of which Ghana is a typical example. Such countries can experience a negative growth impact of exports in two ways: First, heavy dependence on raw material exports may result in a shift away from the manufacturing sector-which has strong forward and backward linkages with other sectors of the economy-towards the primary export sectors-such as the extractive industry with lower inter-linkages and employment levels (Dreger and Herzer, 2013). Second, heavy dependence on the export sector, exposes the economy to external shocks thereby creating frequent episodes of macroeconomic instability with obvious negative implications on economic growth. Now, given that the export sector of the Ghanaian economy is largely dominated by primary commodity exports including, gold, cocoa, diamond, crude oil, etc., the above reasons suffices for the negative impact of export on growth as obtained in this study.

Next, we complement our analysis by accounting for the role of financial development, capital stock and foreign aid on economic growth in Ghana. Our resultindicates a positive and significant long run effect of financial development on economic growth. This result in line with Patrick' (1966) Supply-Leading Hypothesis suggest that a liberalized financial sector is a conduit for economic growth via increasing the productivity of investment and mobilizing savings for private sector development. The results from this paper of a finance-ledgrowth phenomena lends support to the findings of Kargbo and Adamu (2009) and Adu et al. (2013).

Interestingly, the study found out that gross capital formation and foreign aid are not growth inducing factors in the Ghanaian context, as they both have negative and significant effects on economic growth. Minoiu and Reddy (2009, pp. 3) argues that “....aid may inhibit development by creating a dependency mentality and overwhelming the management capacity of governments (Kanbur, 2000), crowding out private sector development (Bauer, 1976; Krauss, 1983), worsening bureaucratic quality (Knack and Rahman, 
2007), weakening governance (Knack and Rahman, 2000; Rajan and Subramanian, 2007) and lowering competitiveness through Dutch Disease effects (Rajan and Subramanian, 2005)". Also it has been acknowledged that the often stringent conditionalities attached to aid to poor countries account for their growth-depressing impact. Such conditionalities make it difficult to derive the ultimate benefits from the Aids. Again, the interest payment on these loans in the long run imposes constraints on incomes of developing economies in providing infrastructure, etc. These factors account for the negative impact of aid on economic growth negative in the long run.

On the relationship between capital stock and output, the outcome is mixed, depending on whether exports are accounted for in the computation of the real GDP or otherwise. In the non-export GDP model, capital stock exerts a positive impact on output, but remains insignificant in all variant specifications except one. Thus one can argue that the result here is not robust. The negative impact of capital stock can be attributed to the high level of capital flight associated with foreign direct investments in developing economies. In many developing economies like Ghana, the extractive sector is the largest recipient of FDI. These sectors are also highly capital intensive with relatively low employment and inter-linkages to other sectors of the economy. More worrying has been the rising trend of capital-flight by these foreign firms with little re-investment in the economy. These factors among others could account for the negative nexus.

Finally, onthe variance decomposition, it could be seen that for every one standard deviation shock, contribution of most factors increases with time. Aside real non-export output itself, financial development, energy consumption, capital stock, exports and Aid account respectively for the highest share of variations in real non-export GDP in decreasing order. However, it must be emphasized that the contribution of energy consumption to shocks in nonexport GDP increases steadily throughout the 10 period. The contributions of exports on the other hand remain marginal throughout the period. Thus, the result shows that contributions to variations in real output are relatively high for aid and capital but moderate for energy consumption and exports.

\section{Conclusions and Implications for Policy}

The purpose of this study is to access the contributions of energy consumption and exports on economic growth in the context of an emerging economy-Ghana. Further to this, the paper seeks to delineate the contributions of these factors on variations (shocks) in aggregate output in Ghana. Results stemming from this paper are of importance to the design of policy to harness the full potentials of an efficient energy and export sectors towards achieving the over-arching goal of promoting sustainable economic development.

Our results identify energy consumption, capital and financial as positive long run drivers of growth in Ghana, whiles foreign aid and exports are less favourable to promoting growth. Specifically our results confirm the energy-growth hypothesis, suggesting that enhancing access and use of energy services is an important conduit for growth; thus energy conservation is inimical to growth. In other words, efficient supply of energy is sinequa-non to the attainment of the economic development of the Ghanaian economy, hence measures to ensure improved access to stable energy supply (especially electricity) is imperative. This reinforces calls for further investments into the country's Rural Electricification Project (REP) and the Self-Help Electrification Programme (SHEP) to boost access to electricity from the current $72 \%$ (in 2011) to universal access. Also, liberalization of the electricity subsector will attract more firms into the production and distribution of electricity, as the status quo has failed to deliver efficient supply of energy to end user, thereby stifling growth. A potent way to unravel the situation is for government to ease the process of registration and establishment of Independent Power Producers (IPP) into developing micro and macro grid systems to increase electricity supply. Further the establishment of a power trading company to issue licence and service agreements to the private partners (IPP) will be worthwhile. In the petroleum and gas subsector, critical attention must be given towards eliminating the numerous challenges relating to LPG supply and distribution nationwide. Also the establishment of refineries and allied industries is important to ensure integration of the country's burgeoning oil and gas industry into the economy to provide the requisite forward and backward linkages to other sectors of the economy. This will increase supply of energy services whiles generating employment and income to fuel economic growth in the country.

Further, our results on export draw an important attention for policy in Ghana. It calls for wellcoordinated efforts aimed putting value addition at the heart of export promotion policy design in the country so as to induce real economic growth. Also, efforts aimed at promoting non-traditional exports must be intensified so as to adequately diversify the country's export market to reduce the vulnerability of the economy to adverse external shocks while at the same time maximizing export revenues to boost macroeconomic stability and growth. Finally, integration of energy and pro-export policies can be welfare enhancing.

\section{Acknowledgement}

Special thanks to the maker of heaven and earth. I acknowledge the effort of Dr. Justice Tei Mensah and all friends in academia. 


\section{Funding Information}

I did not receive any form of funding from any organization or individual. The cost for this article was incurred by the author alone.

\section{Ethics}

EthicsThis article is original and contains unpublished material. The author confirms that he has read themanuscript carefully and approve for publication. There are no ethical issues involved.

\section{References}

Adom, P.K., 2011. Electricity consumption-economic growth nexus: The Ghanaian case. Int. J. Energy Econ. Policy 1: 18-31.

Adu, G., G. Marbuah and J.T. Mensah, 2013. Financial development and economic growth in Ghana: Does the measure of financial development matter? Rev. Dev. Finance, 3: 192-203.

DOI: $10.1016 /$ j.rdf.2013.11.001

Akinlo, A.E., 2008. Energy consumption and economic growth: Evidence from 11 African countries. Energy Econ., 30: 2391-2400.

DOI: $10.1016 /$ j.eneco.2008.01.008

Bauer, P., 1976. Dissent on Development. 1st Edn., Harvard University Press, Cambridge, ISBN-10: 0674212827, pp: 230.

Cornia, G.A. and G. Helleiner, 1994. From Adjustment to Development in Africa - Conflict, Controversy, Convergence, Consensus? 1st Edn., St Martin's Press, New York, ISBN-10: 9780333613610, pp: 417.

Dreger, C. and D. Herzer, 2013. A further examination of the export-led growth hypothesis. Empirical Econ., 45: 39-60. DOI: 10.1007/s00181-012-0602-4

Engle, R.F. and C.W.J. Granger, 1987. Cointegration and error correction representative, estimation and testing: Econometrica 55: 251-276.

DOI: $10.2307 / 1913236$

Esso, L.J., 2010. Threshold cointegration and causality relationship between energy use and growth in seven African countries. Energy Econ. 32: 1383-1391. DOI: $10.1016 /$ j.eneco.2010.08.003

Greenaway, D. and D. Sapsford, 1994. What does liberalisation do for exports and growth? Rev. World Econ., 130: 152-174.

Greene, W., 2012. Econometric Analysis. 7th Edn., Prentice-Hall, New York, ISBN-10: 0273753568, pp: 1228.

Guttormsen, A.G., 2004. Causality between energy consumption and economic growth. Department of Economics and Resource Management, Agriculture University of Norway.
Halicioglu, F., 2011. Adynamiceconometric study of income, energy and exports in Turkey. Energy, 36: 3348-3354.

Helpman, E. and P.R. Krugman, 1985. Market Structure and Foreign Trade. 2nd Edn., MIT Press, Cambridge, MA, ISBN-10: 0585113009, pp: 288.

Johansen, S. and K. Juselius, 1990. Maximum likelihood estimation and inference on cointegration with applications to the demand for money. Oxford Bull. Econ. Stat. 52: 169-210. DOI: $10.1111 / \mathrm{j} .1468-0084.1990 . \mathrm{mp52002003.x}$

Kanbur, R., 2000. Aid, Conditionality and Debt in Africa. In: Foreign Aid and Development: Lessons Learnt and Directions for the Future, Tarp, F. and P. Hjertholm (Eds.), Routledge, New York, ISBN-10: 0415215463, pp: 409-422.

Kargbo, S.M. and P.A. Adamu, 2009. Financial development and economic growth in Sierra Leone. J. Monetary Econ. Integrat., 9: 30-61.

Killick, T., 1996. Principals, agents and failing conditionality. Proceedings of the Annual Conference of Development Studies Association, (DSA'96), University of Reading.

Knack, S. and A. Rahman, 2007. Donor fragmentation and bureaucratic quality in aid recipients. J. Dev. Econ., 83: 176-197. DOI: $10.1016 /$ j.jdeveco.2006.02.002

Knack, S. and A. Rahman, 2000. Aid dependence and the quality of governance: A cross-country empirical analysis. World Bank Policy Research Working Paper No. 2396 Washington.

Krauss, M.B., 1983. Development without Aid: Growth, Poverty and Government. 1st Edn., McGraw-Hill, New York, ISBN-10: 0070354685, pp: 208.

Lancaster, K., 1980. Intra-industry trade under perfect monopolistic competition. J. Int. Econ., 10: 15-175. DOI: 10.1016/0022-1996(80)90052-5

Lean, H.H. and R. Smyth, 2010. On the dynamics of aggregate output, electricity consumption and exports in Malaysia: Evidence from multivariate Granger causality tests. Applied Energy, 87: 1963-1971. DOI: 10.1016/j.apenergy.2009.11.017

Mensah, J.T., 2014. Carbon emissions, energy consumption and output: A threshold analysis on the causal dynamics in emerging African Economies. Energy Policy, 70: 172-182.

DOI: 10.1016/j.enpol.2014.03.038

Mensah, J.T., 2013. Time varying dynamics of aggregate energy demand in Ghana. Working Paper, Department of Economics, Swedish University of Agricultural Sciences.

Minoiu, C. and S.G. Reddy, 2009. Development aid and economic growth: A positive long-run relation. IMF Working Paper WP/09/118. 
Narayan, P.K. and A. Prasad, 2008. Electricity consumption-real GDP causality nexus: evidence from a bootstrapped causality test for 30 OECD countries. Energy Policy, 36: 910-918. DOI: 10.1016/j.enpol.2007.10.017

Odhiambo, N.M., 2009. Electricity consumption and economic growth in South Africa: A trivariate causality test. Energy Econ., 31: 635-640. DOI: $10.1016 /$ j.eneco.2009.01.005

Ouedraogo, N.S., 2013. Energy consumption and economic growth: Evidence from the economic community of West African States. Energy Econ., 36: 637-647. DOI: 10.1016/j.eneco.2012.11.011

Ozturk, I., 2010. A literature survey on energy-growth nexus. Energy Policy, 38: 340-349. DOI: 10.1016/j.enpol.2009.09.024

Patrick, H.T., 1966. Financial development and economic growth in underdeveloped countries. Econ. Dev. Cultural Change, 14: 174-189. DOI: 10.1086/450153

Payne, J.E., 2010. A survey of the electricity consumption-growth literature. Applied Energy, 87: 723-731. DOI: 10.1016/j.apenergy.2009.06.034

Phillips, P.C.B. and B.E. Hansen, 1990. Statistical inference in instrumental variables regression with I (1) processes. Rev. Econ. Stud., 57: 99-125. DOI: $10.2307 / 2297545$

Rajan, R. and A. Subramanian, 2007. Does aid affect governance? Am. Econ. Rev., 97: 322-327. DOI: 10.1257/aer.97.2.322

Rajan, R. and A. Subramanian, 2005. What undermines aid's impact on growth? NBER Working Paper No. 11657 (National Bureau of Economic Research, Cambridge, MA.).

Siliverstovs, B. and D. Herzer, 1994. Manufacturing exports, mining exports and growth: Cointegration and causality analysis for Chile (1960-2001). Applied Econ., 39: 153-167.

DOI: $10.1080 / 00036840500427965$
Sims, C., 1972. Money, income and causality. Am. Econ. Rev., 62: 540-552.

Soytas, U. and R. Sari, 2003. Energy consumption and GDP: Causality relationship in G-7 countries and emerging markets. Energy Econ., 25: 33-37.

DOI: 10.1016/S0140-9883(02)00009-9

Stewart, F., 1991. Are adjustment policies in Africa consistent with long-run development needs? Dev. Policy Rev., 9: 413-436.

DOI: 10.1111/j.1467-7679.1991.tb00196.x

Twerefo, D.K., S.K.K. Akoena, F.K. Egyir-Tettey and G. Mawutor, 2008. Energy consumption and economic growth: Evidence from Ghana. University of Ghana, Ghana.

UNRISD, 1995. Adjustment, globalization and social development: Report of the URISD/UNDP International Seminar on Economic Restructuring and Social Policy. United Nations Research Institute for Social Development, Geneva.

Wolde-Rufael, Y., 2009. Energy demand and economic growth: The experience of African countries revisited. Energy Econ., 31: 217-224. DOI: 10.1016/j.eneco.2008.11.005

Wolde-Rufael, Y., 2006. Electricity consumption and economic growth: A time series experience for 17 African countries. Energy Policy, 34: 1106-1114. DOI: 10.1016/j.enpol.2004.10.008

Yoo, S.H. and S.G. Kwak, 2010. Electricity consumption and economic growth in seven South American countries. Energy Policy, 38: 181-188. DOI: $10.1016 /$ j.enpol.2009.09.003

Zachariadis, T., 2007. Exploring the relationship between energy use and economic growth with bivariate models: New evidence from G-7 countries. Energy Econ., 29: 1233-1253. DOI: $10.1016 /$ j.eneco.2007.05.001 